\title{
Aikalaisanalyysia suomalaisen yliopiston tilasta
}

Rinne, R., Jauhiainen, A., Simola, H., Lehto, R., Jauhiainen, A. \& Laiho, A. (2012): Valta, uusi yliopistopolitiikka ja yliopistotyö Suomessa. Managerialistinen hallintapolitiikka yliopistolaisten kokemana. Kasvatusalan tutkimuksia 58. Jyväskylä: Suomen kasvatustieteellinen seura. 392 s. ISBN 978-952-5401-60-8.

VALTA, UUSI yliopistopolitiikka ja yliopistotyö Suomessa.on syntynyt kahden koulutussosiologisesti suuntautuneen tutkijaryhmän yhteisponnistuksena. Siinä yhdistyvät Helsingin yliopiston Foucault-viritteinen hallinnan tutkimuksen perinne sekä Turun yliopiston korkeakoulupolitiikan tutkimuksen kriittinen perinne.

Suomen Akatemian tutkimusohjelma Valta Suomessa on toiminut jalustana, jonka varassa nämä kaksi tutkimusryhmää ovat voineet yhdistää voimansa ja kirjoittaa tämän tärkeän aikalaisanalyysin yliopistotyöntekijöiden arjen nykytilasta Suomessa. Konkreettinen empiirinen analyysi tulee tarpeeseen aikana, jolloin Suomen valtion poliittisen johdon sekä yliopistojen johdon suusta kuulee edelleen julistettavan meneillään olevan yliopistouudistuksen "fantastisuutta" sekä sitä, että juuri yliopistolaiset itse ovat tämän uudistuksen itselleen halunneet. Muutoksen agentteja tosin taisivat olla lähinnä yliopistojohto ja ylin hallintoeliitti, joka on tuonut erityisesti rehtorien neuvoston (nykyisen Suomen Yliopistot UNIFI ry) kautta reformia yliopistoihin (Vanttaja 2010, 192-193, Välimaa 2011,73-75).

\section{KILPAILUKULTTUURIN ODOTUKSET}

Kirjan analyysissä kysytään, miten yliopistoreformiin suhtaudutaan tämän pienen hallintaeliitin ulkopuolella yliopistojen arjessa, jossa kohdataan uudenlaiset hallinnan ja vallankäytön teknologiat kaikessa rujoudessaan. Johtopäätöksiä yliopistojen arjesta tehdään kahden yliopiston, Turun ja Joensuun koko opetus- ja tutkimushenkilökunnalle sekä lisäksi näiden yliopistojen koko hallinto-, kehittämis- ja suunnitteluhenkilökunnalle suunnatun laajan kyselyn perusteella. Tarkasteluun on valittu yliopistot, joissa on viime vuosina toteutettu suuria hallinnollisia uudistuksia. Näiden yliopistojen erityistilanteita analyysi ei kuitenkaan tarkemmin käsittele.

Teoreettiseksi taustakuvaksi analyysissä rakennetaan globaalin markkinamuutoksen maisema, joka on siirtänyt yliopistot kilpailu(kyky)valtion talouden edistämisen keskiöön. Muiden yhteiskunnallisten palvelujen tapaan myös yliopistoihin suuntautuu "suorittavan kilpailukulttuurin" odotukset. Teoksen tutkijoita kiinnostavat yliopistoväen tunnot, kokemukset ja näkemykset murrosten keskellä. Teoksessa ol- laan kiinnostuneita yliopistotyön muuttuvista valtasuhteista ja uusista vallan teknologioista ja siitä, miten nämä teknologiat vaikuttavat yliopistolaisten kokemuksiin ja näkemyksiin ja sen kautta myös arjen toimintaan. Tutkimuksen empiirisessä analyysissä kysytään muun muassa, miten uusi palkkausjärjestelmä, tiivistynyt ajankäytön seuranta, vuoden 2005 tutkinnonuudistus tai laatujärjestelmien kehittelytyö koetaan ruohonjuuritason yliopistolaisten perustyössä.

\section{MUUTTUNUT SANASTO OHJAA TOIMINTAA}

Aineistojaan kirjan kirjoittajat pohjustavat teoreettisesti käsitteellistämällä vallan olemusta ja symbolista vallankäyttöä uudessa yliopistopolitiikassa sekä kansainvälisen että kansallisen keskustelun näkökulmasta. Valtateoreettisiksi perusajatuksiksi esitetään Foucault'n valta-analyysin keskeiset ideat vallankäytön produktiivisesta luonteesta, jonka mukaan vallankäyttö etenee itsehallinnan ja oman käyttäytymisen tarkkailun ja säätelyn kurinalaisuuden sisäistämisen kautta itsevalvontaan. Itsevalvontaa puolestaan tuetaan paimentavan eli pastoraalisen val- 
lankäytön eikä niinkään pakottavien käytäntöjen kautta. Tutkijat ovat kiinnostuneita uudenlaisten totuuksien tuottamisen prosesseista, joiden kautta myös yliopistolaitosta ja sen perustavia tehtäviä määritellään uudelleen. Tämä siirtymä tiivistetään teoksessa siirtymäksi kohti yritysyliopiston markkinakuria, managerivaltaa sekä erinomaisuuden eetosta.

Ensivaiheessa kysymys on lähinnä puheavaruuden muutospyrkimyksistä eli lisääntyvästä pakosta artikuloida toimintaa kulloisenkin hegemonistisen diskurssin ehdoin. Näin yliopistolaiset jäävät managerialistisen sanaston ja sanojen vangeiksi. Muuttuneet sanastot vaikuttavat siihen, mitä yliopistoilta ja yliopistotyöltä odotetaan. Talouden ja yritysmaailman sanasto ohjaa yliopistolaisia kuin hiipien mieltämään yliopiston tehtävät uudella tavalla, joka johtaa heidät vähitellen sisäistämään uudenlaisen markkinoiden logiikan ja eetoksen. Tällä hetkellä yliopistoihin ollaan juurruttamassa ideaa kansainvälisten konsulttifirmojen tekemistä "asiakastyytyväisyysmittauksista", jotka opiskelijapalautteen muodossa tulevaisuudessa vaikuttavat myös yksikköjen rahanjakoon (ks. esim. Acatiimi 8/2012, 36-37).

Aiemmin on yliopistoihin jo juurrutettu puhe tohtori- ja maisterituotannosta, mikä ei enää samassa määrin särähdä yliopistolaisten korvaan kuin aiemmin.
Opetuksen ja tutkimuksen vapauteen ja autonomiaan kasvaneiden akateemisten työntekijöiden muokkaus ja sitouttaminen kehittämiskeskustelujen ja alaisvalmennuksen ja uudenlaisten johtaja- ja esimiesasemien hyväksyntään on meneillään. Myös managerijohtajuus yritysjohtajuuden muotona on sivuuttamassa ja korvaamassa tieteenalojen sisäisen kollegiaalisen ja professorijohtoisen itsehallinnan, jonka mukaan tutkimusalan edustajilla on oikeus ja velvollisuus kontrolloida itse itseään. Oman tiedeyhteisön perinteiset arviointikäytännöt korvataan yritysyliopiston ulkopuolisilla arviointi- ja auditointikäytännöillä, jotka irtoavat tieteenalojen edustajien kontrollista. Samalla uuden yritysyliopiston managerijohtaja näyttäytyy uuden politiikan sankarina, jonka tehtävänä on juurruttaa uudenlaista asenneilmastoa ja kulttuuria yliopiston arjen ruohonjuuritasolle sekä ylläpitää eräänlaista sepitteellistä sielujen hallintaa.

Stephan Ballin (Ball 2003,224) teksteihin viitaten tutkijaryhmä määrittelee sepitteellisyyden strategiseksi toiminnaksi, joka nyt ei suorastaan ole valhe, vaan eräänlainen sepite, joka tuotetaan vaikutelmien luomiseksi ulkopuolisille tilivelvollisuuden vuoksi. Nyky-yliopiston tila tuo mieleeni elävästi George Orwellin kirjan Vuonna 1984 (1949/1987, 43), jossa hän kertoo pelottavalla tavalla samankaltaisesta maailmasta, jossa puolueen työntekijät joutuvat varustamaan itsensä eräänlaisella uudiskielellä ja kaksoisajattelulla. Sen mukaan "pitää tietää ja olla tietämättä, olla selvillä asiain todellisesta tilasta ja ladella huolella sepitettyjä valheita, olla yhtä aikaa kahdella eri kannalla, tietää että ne poissulkevat toisensa ja uskoa silti kumpaiseenkin". Ballin $(2003,220)$ teksteihin viitaten myös tässä tutkimuksessa kerrotaan, miten yliopistot varustautuvat tehokkuuden kulisseilla ja ne päätyvät eräänlaiseen "arvojen skitsofreniaan", jossa työtekijät joutuvat kysymään itseltään "teemmekö tätä siksi, että se on tärkeätä, koska me uskomme siihen ja koska se on arvokasta? Vai tehdäänkö sitä viime kädessä siksi, että sitä mitataan, arvioidaan ja vertaillaan”?

\section{PERINTEISET ARVOT YHÄ TÄRKEITÄ}

Teoksen empiirisessä analyysissä keskiöön nostetaan suomalaisten yliopistolaisten kokemukset ja näkemykset vallan uusista teknologoista, joita he yliopiston arjessa kohtaavat. Teoksessa ollaan myös kiinnostuneita siitä, miten yliopistolaiset Suomessa suhtautuvat yritysyliopiston markkinakurin epäluottamuksen kulttuuriin, jossa työntekijät joutuvat jatkuvan ulkopuolisen kontrollin kohteeksi. Entä miten yliopistolaiset suhtautuvat tilanteeseen, jossa he joutu- 


\section{TuloKseT}

VIITTAAVAT SIIHEN, ETT $\ddot{A}$ YLIOPISTO-

vat jatkuvalla työnsä "näytteillepanolla" toistuvasti todistelemaan omaa tarpeellisuuttaan. Valvovan silmän alaisuudessa oleminen luo ontologisen epävarmuuden ja jatkuvan varuillaanolon kulttuurin, joka hiipii yliopistoihin lisääntyneenä vertailuna, rankkauksina ja kilpailutuksina. Kun muodolliset indikaattorit nousevat tärkeimpään rooliin, joudutaan työn arjessa todistamaan varsinaisen yliopistojen hengen rapautumisen prosessista. Se vie perustan kriittiseltä ja tieteen omilla ehdoilla toimivalta yliopistoyhteisöltä, joka tavoittelee uutta tietoa ja uudenlaisia kiinnostavia kysymyksenasetteluja.

Tutkimuksen laaja-alaisella kyselyllä selvitetään, miten toiminnan perusteluissa ja diskursseissa tapahtuneet muutokset näkyvät toimijoiden välisissä suhteissa ja asemissa akateemisilla kentillä ja miten uudenlainen valta ja hallinta läpäisevät ihmisten jokapäiväisen toimintaympäristön ja arjen rutiinit. Kyselyssä esitettiin erilaisia väitteitä, joihin eri tieteenalojen eri-ikäiset, eri sukupuolta olevat, erilaisella työkokemuksella varustetut ja eri asemassa toimivat henkilöryhmät ottivat kantaa. Survey-tutkimuksella tuotettiin kattavia vertailuasetelmia, joita tutkimuksessa tarkasteltiin huolellisesti, vaikkakin hieman yllätyksettömällä tavalla. Tehty tutkimus osoittaa kuitenkin hyvin selvästi sen, että edelleen yli- opistotyön perustasolla suurin osa yliopistotyöntekijöistä sitoutuu vahvasti akateemisen yhteisön traditionaalisiin arvoihin, jotka liittyvät tutkimuksen, opetuksen ja tieteen autonomian puolustamiseen. Kirjan analyysi osoittaa myös, että noin puolet myös hallinnon työntekijöistä samaistuu ja sitoutuu ensisijaisesti oman yksikkönsä tutkimus- ja opetushenkilökuntaan. Valtaenemmistö vastaajista kokee myös palkkatasoa selvästi nostaneen uuden palkkausjärjestelmän epäoikeudenmukaiseksi ja nöyryyttäväksi. Se vaikeuttaa yhteistyötä ja yhteishenkeä sekä yliopiston perustyötä opetuksen ja tutkimuksen äärellä.

Tutkijat kertovat, että he halusivat antaa äänen yliopiston "lattiatason" ja "verstaskerroksen" työntekijöille. Parhaiten tämä mahdollistui avovastausten kautta. Analyysissä juuri avovastausaineisto avasi yliopistojen murroksessa olevaa arjen kulttuurista tilaa kuvittamalla ja rikastamalla tässä tutkimuksessa tehtyä tilastollista analyysiä. Avovastauksien tekstiaineistoa olisi ollut kiinnostavaa avata myös tarkempaa retorista analyysiä tekemällä. Tutkijat viittaavat siihen, että vastauksissa käytettiin suorastaan alatyylisiä, ironisia ja sarkastisia ilmaisuja. Olisi ollut kiintoisaa tietää, mistä ja miten eri sukupuolta edustavat, eri asemissa ja tieteenaloilla toimivat yliopistolaiset kulloinkin avovastauksissaan hakivat ne vaihtoeh-
LAITOKSESTA LÖYTYY

EDELLEEN SITKË̈STI

TUTKIMUKSELLEEN

JA OPETUKSELLEEN

OMISTAUTUNEITA

HENKILÖIT $\ddot{A}$.

toiset sanastot, joilla he purkavat kärjekkäimpiä ärsytyksiin, pettymyksiään ja nolatuksi tulemisen tunteitaan suhteessa uudenlaisiin vallankäytön teknologoihin.

\section{VALTA KATOAA \\ KESKUSHALLINTOON}

Teoksen alussa todetaan, että yliopistoissa onnistuvat harvoin äkkinäiset ja perustavanlaatuiset muutokset ja muutospyrkimykset. Sopii vain toivoa, että näin todella olisi asioiden laita tässäkin tapauksessa. Tulokset viittaavat siihen, että yliopistolaitoksesta löytyy edelleen sitkeästi tutkimukselleen ja opetukselleen omistautuneita henkilöitä, jotka kovista aika-, suoritus- ja mittauspaineista huolimatta jaksavat edelleen löytää työstään mielen ja mielekkyyden. Tutkimuksen analyysi osoittaa myös hyvin selvästi sen, että yliopistotyön ruohonjuuritasolla ylintä hallintoeliittiä lukuun ottamatta suhtautuminen uusiin vallan teknologioihin on hyvin kriittistä ja torjuvaa ja traditionaalisia akateemisia arvostuksia säilyttävää. 
Yliopistolaiset suhtautuivat esimerkiksi hyvin kriittisesti ja epäluuloisesti valtakunnan tason päätöksentekijöihin, joiden linjauksista he tosin kertovat olevansa aika huonosti perillä. Myös oman yliopiston keskushallinnon suunnitelmat ja päätökset näyttävät jääneen yliopistolaisille yllättävän vieraiksi ja etäisiksi, toisin kuin oman yksikön asiat, joista valtaenemmistö (80\%) kertoi edelleen tietävänsä hyvin tai melko paljon. Kiinnostavaa olisi tietää, missä määrin tietoisuus oman yksikön yhteisten asioiden hoidosta on jo tämänkin tutkimuksen tekemisen jälkeen muuttunut. Monissa yliopistoissa on siirrytty yhä suurempiin ja heterogeenisimpiin perusyksiköihin, joissa perinteistä yliopiston kollegiaalista päätöksentekoa ja lähidemokratiaa on romutettu ja siirrytty yhä johtajakeskeisempiin toimintakäytäntöihin ja toimintakulttuuriin. Johtajakeskeisyyden lisääntyminen on nopeasti muuttanut kollegiaalisen vastuun kulttuuria huonompaan suuntaan. Yliopistolaiset kokevat yhä enemmän myös oman työyksikkönsä asiat itselleen vieraiksi ja tulevaisuuteen vaikuttamisen itselleen yhä vaikeammaksi asiaksi.

Uuden yritysyliopiston hallintoreformaattorit ovat todella taitavalla "hallitse ja hajota" -politiikallaan luoneet yliopistoihin tilanteen, jossa keskinäistä kilpai- lua, aika- ja suorituspaineita lisäämällä, hallintoa keskittämällä ja yliopiston kokonaistyöilmapiiriä erilaisilla toimimattomilla teknologisilla järjestelmillä heikentämällä on luotu tila, josta yksittäiset tuloksentekijät yrittävät selvitä omin avuin tilanteista toiseen. Yliopistolaisille on tehty lähes mahdottomaksi löytää ulospääsyä managerivetoisesta yritysyliopistosta, jossa enemmistö yliopistolaisista näyttää voivan erittäin huonosti.

\section{TÄRKEÄ AJANKUVA}

Olisi ollut kiinnostavaa pohtia hieman enemmän kirjan kirjoittajien useassa yhteydessä virittämää ajatusta pehmeistä ja kovista tieteistä ja näiden jakojen suhteesta erityisesti kasvatustieteisiin. Kasvatustieteilijät eivät näytä itsestään selvästi sijoittuvan humanistien ja yhteiskuntatieteilijöiden kanssa niin sanottujen pehmeiden tieteiden asenneilmastoon. Tutkimuksen tulokset viittaavat jossain määrin siihen, että kasvatustieteilijät lääketieteilijöiden rinnalla edustavat selvemmin tutkimusaloja, jotka pitävät tärkeänä yliopistojen strategia- ja tavoitetyötä. Kasvatustieteilijät näyttävät tutkimuksen tulosten mukaan arvostavan virallisia tavoitteita ja strategioita hallinnon kaikilla tasoilla. Ovatko kasvatustieteilijät ehkä myös taipuvaisempia uskomaan yritysyliopiston strategiatyön sepitteellisyyteen ja ylhäältä alas johdetun markkinakurin teknologoihin? Olisi ollut kiintoisaa tarkastella tämän tyyppisiä alakohtaisia kulttuurieroja tutkimuksen aineiston kautta hieman tarkemmin. Tämän tyyppiset alakohtaiset kulttuuriset kysymyksenasettelut voisivat toimia myös jatkotutkimuksen virikkeenä.

Arvioitu teos ja tutkimusprojekti ajoittuvat ajankohtaan, jolloin uusi yliopistolaki oli vasta tuloillaan. Samoin monet yliopistojen rakenteelliset ja kulttuuriset uudistukset olivat myös tutkimusajankohtana jatkuvassa liikkeessä. Muutostilanne lisää tämän tutkimushankkeen erityistä arvoa tärkeänä ajankuvana, joka ottaa kiinni liikkuvasta kohteesta ehkä myös liikkeen suuntaan omalta osaltaan näin vaikuttaen. Suosittelen tämän kirjan lukemista kaikille, jotka haluavat tietää hieman enemmän siitä, mitä mieltä varsinainen yliopistoväki on meneillään olevista yliopistouudistuksista. Tilanne ei selviä pelkästään yliopistojen johtajien kauniita strategiasepitteitä lukemalla.

\section{Karin Filander}

dosentti, yliassistentti

Tampereen yliopisto,

Kasvatustieteiden yksikkö 